\title{
Persepsi, Motif, dan Perubahan Perilaku Jama'ah Umrah Pada Biro Travel Haji dan Umrah Kota Kediri
}

\author{
Muhamad Aqim Adlan \\ Institut Agama Islam Negeri Tulungagung, Indonesia \\ adlanaqim1@gmail.com
}

\begin{abstract}
The purpose of this study is to determine the perceptions, motives, and changes in behavior of the Umrah pilgrims at the Haj and Umrah travel agencies in Kediri. This is based on the problem of waiting time for the pilgrimage to depart. So that some Muslims chose Umrah as an alternative to immediately go to Mecca.However, this condition provoked some irresponsible travel agencies to take a chance. This study uses a qualitative research method with the type of case study research. The findings in this study indicate that: First, the perception of Umrah pilgrims on the existence of an Umrah travel agency is still very much needed today because its existence is very helpful in facilitating the process of carrying out the Umrah pilgrimage. Second, there are two different motives for performing the Umrah pilgrimage within the Umrah congregation, namely the motive for worship and others. Third, Umrah has an impact on better behavior than before.
\end{abstract}

Keywords: Perception, Motives, Behavior Change, Umrah pilgrims

\begin{abstract}
Abstrak
Tujuan dari kajian ini adalah guna mengetahui persepsi, motif, dan perubahan perilaku jama'ah umrah pada biro travel haji dan umrah Kota Kediri. Hal ini didasarkan pada permasalahan lamanya menunggu pemberangkatan ibadah haji. Sehingga beberapa kaum muslim memilih umrah sebagai alternatif untuk segera berangkat menuju Mekkah. Namun ternyata kondisi tersebut memancing beberapa biro travel yang tidak bertanggungjawab untuk mengambil sebuah kesempatan. Kajian ini menggunakan metode penelitian kualitatif dengan jenis penelitian studi kasus. Temuan dalam kajian ini menunjukkan bahwa: Pertama, persepsi jamaah umrah terhadap keberadaan biro travel perjalanan umrah dirasakan masih sangat dibutuhkan saat ini dikarenakan keberadaannya sangat membantu guna mempermudah proses pelaksanaan ibadah umrah. Kedua, terdapat dua motif yang berbeda dalam menunaikan ibadah umrah dalam diri jamaah umrah, yaitu motif ibadah dan lain. Ketiga, umrah memberikan dampak kepada perilaku yang lebih baik dari sebelumnya.
\end{abstract}

Kata Kunci: Persepsi, Motif, Perubahan Perilaku, Jamaah Umrah

\section{Pendahuluan}

Ibadah haji merupakan ibadah yang mempertaruhkan jiwa, raga, keimanan, harta, benda, tenaga, waktu dan lain sebagainya, sehingga keinginan kaum muslim yang mendaftarkan diri untuk melaksanakan haji tidak pernah surut. ${ }^{1}$ Perkembangan itu terlihat

\footnotetext{
${ }^{1}$ Budi Kisworo, "Ibadah Haji Ditinjau Dari Berbagai Aspek," Al Istinbath : Jurnal Hukum Islam
} 2, no. 1 (2017).

Tribakti: Jurnal Pemikiran Keislaman

Volume 32, Nomor 1, Januari 2021 
dari jumlah antrian yang semakin panjang dalam setiap tahunnya. ${ }^{2}$ Sekitar 15 sampai 20 tahun yang lalu, jumlah calon haji ini melaksanakan haji dengan tidak mengantri. Mereka yang mendaftar pada tahun tertentu, pada tahun itu pula mereka berangkat. Namun mulai sekitar tahun 2007 terjadi antrian, mereka yang mendaftar di tahun 2007, akan berangkat pada tahun 2009. Tahun-tahun berikutnya, jumlah antrian semakin panjang. Di beberapa daerah Dati II Jawa Timur misalnya mereka yang mendaftar haji di tahun ini, akan diberangkatkan pada 20-35 tahun kedepan. ${ }^{3}$

Kondisi di atas telah menimbulkan beberapa problem yang muncul dengan variasi yang beragam. Dengan persoalan antrian ini menimbulkan beberapa problem, antara lain banyak calon jamaah haji berusia senja yang gelisah, karena khawatir sisa umurnya tidak cukup mengantarkannya pada saat jadwal pemberangkatan haji tiba. Sebagian lain resah karena dengan lamanya antrian membuat mereka menjadi tua dan lemah fisiknya. ${ }^{4}$

Di sisi lain, sektor bisnis ini oleh sebagian pihak dilihat sebagai sebuah peluang tersendiri. Terdapat lebih dari 350 biro ibadah haji dan umrah yang telah terdaftar secara resmi di Kemenag Pusat. Beberapa biro perjalanan haji bermunculan dengan menawarkan berbagai fasilitas menggiurkan masyarakat yang hendak melaksanakan haji dengan cara khusus (haji plus). Dengan tarif sangat tinggi, biro ini menawarkan fasilitas yang dapat memudahkan para jamaah, seperti; penginapan yang dekat dengan pusat-pusat ibadah, makanan yang istimewa, pendampingan yang dilakukan secara total dan all round di tanah suci, dan masa pelaksanaan yang lebih singkat. ${ }^{5}$

Situasi dan kondisi di atas mengantarkan para muslimin untuk mengambil ibadah umrah sebagai alternatif (jika tidak bisa disebut keterpaksaan). Dengan berbagai strategi pemasaran, sektor ini berhasil menarik minat sebagian masyarakat untuk melaksanakan umrah sebagai alternatif pelaksanaan haji. Paket-paket perjalanan ibadah umrah dibuat sesuai dengan kondisi calon jamaah. ${ }^{6}$ Para jamaah disuguhkan berbagai macam pilihan

\footnotetext{
${ }^{2}$ Ratih Nurmalasari Aishath Muneeza, Amira Shuhadabinti Tamby Sudeen, Atiqoh Nasution, “A Comparative Study of Hajj Fund Management Institutions in Malaysia, Indonesia and Maldives," International Centre for Education in Islamic Finance (INCEIF) 5, no. 3 (2018).

${ }^{3}$ Sambutan Dirjen Penyelenggaraan Ibadah Haji dan Umrah Kemenag, Anggito Abimanyu dalam acara Pembekalan Petugas Media Center Haji 1433 H/2012 di Hotel Grand Cikarang, Bekasi, Jawa Barat, Kamis (6/9) malam. Japeri, "Pengaruh Kuota Terhadap Daftar Tunggu Naik Haji Di Kota Padang," JEBI: Jurnal Ekonomi Dan Bisnis Islam 2, no. 1 (2017).

${ }^{4}$ Hasil Wawancara Dengan Jamaah Umrah Kota Kediri.

${ }^{5}$ Lia Fadilah, "Strategi Dan Manajemen Travel Haji Dan Umrah: Studi Analisis Persaingan Travel Haji Dan Umroh Kota Medan Dalam Pelayanan Dan Kualitas Untuk Meningkatkan Jumlah Konsumen,” Al-Muamalat: Jurnal Hukum Ekonomi Syariah IV, no. 1 (2019): 3.

${ }^{6}$ Akhmad Anwar Dani, "Problematika Pengelolaan Penyelenggaraan Umrah Di Kota Surakarta," Ilmu Dakwah: Academic Journal for Homiletic Studies 12, no. 1 (2018): 24.
} 
waktu yang disesuaikan dengan kelonggaran jamaah. Waktu pelaksanaan pun diberikan pilihan dari mulai 7 hari, 9 hari sampai 14 hari. Berbagai wisata ke tempat-tempat bersejarah pun dimasukkan dalam paket umrah ini, seperti wisata ke Masjid al-Aqsa di Yerussalem, Piramida di Mesir, tempat wisata di negara Turki, Yordania, Abu Dhabi, dan tempat-tempat wisata lainnya di Timur Tengah. Semua itu tentu saja disediakan untuk memberikan pilihan lebih variatif sesuai keinginan, kebutuhan dan kekuatan finansialnya. ${ }^{7}$ Paket umrah ini dipilih masyarakat tidak saja untuk beribadah ke Baitullah sebagai pengganti haji, namun juga mereka bisa menikmatinya dengan berwisata ke tempat-tempat bersejarah dalam Islam. "Sekali dayung, dua tiga pulau terlampaui", kebutuhan rekreasi tercapai dan dapat pahala lagi.

Mereka, para biro travel memanfaatkan situasi di tengah mahalnya biaya haji dan antrian panjangnya dengan cara membuka layanan ziarah haji. Mereka menggunakan visa turis dan menginap di perumahan para mukminin. Mereka bisa tinggal berbulan-bulan disana dan menikmati ibadah di masjidil haram sepuas-puasnya. Mereka juga bisa menikmati ibadah di masjidil haram pada saat bulan ramadhan. Namun, dalam pelaksanaan ibadah haji, mereka melaksanakannya secara mandiri, tidak seperti jamaah haji yang penyelenggaraannya diurusi pemerintah. Ini karena mereka tidak terdaftar sebagai jamaah haji.

Di tengah situasi yang sangat kompleks tersebut, secara internal, para jamaah dihadapkan pada motif-motif yang beragam. Umrah sebagaimana ibadah haji bagi sebagian masyarakat masih dianggap sebagai sesuatu yang bisa mendatangkan kehormatan dan kemuliaan. ${ }^{8}$ Masyarakat yang telah berlabel haji ataupun seringnya berpergian untuk melaksanakan umrah akan mendapatkan perhormatan khusus dari masyarakat dibanding dengan mereka yang belum melaksanakannya. Dengan penghormatan khusus ini, maka mereka akan mempunyai akses lebih luas dalam membentuk masyarakat, karena status sosialnya telah meningkat bukan lagi sebagai orang biasa, tetapi sebagai orang yang menentukan. ${ }^{9}$ Dengan demikian semakin kuat pula posisinya di masyarakat.

\footnotetext{
${ }^{7}$ Syaiful Anwar \& Dida Hilpiah, "Perancangan Aplikasi Pendaftaran Umrah Berbasis Web Pada Nurrahma Tour \& Travel," INTI NUSA MANDIRI 15, no. 1 (2020).

${ }^{8}$ Sri Walyoto \& Jasanta Paranginangin, "Analysis On Demand For Umrah Bailout Fund In Indonesia," International Journal of Civil Engineering and Technology (IJCIET) 9, no. 13 (2018): 1247.

${ }^{9}$ Ricco Andreas M. Nasrun Nazaruddin, Rahmat Hidayat, "Analisis Strategi Pemasaran Dan Pelayanan Dalam Upaya Peningkatan Daya Saing Biro Perjalanan Haji Dan Umrah Perspektif Ekonomi Syariah (Studi Pada PT. Makkah Multazam Safir Dan Al Madinah)," NIZHAM 8, no. 1 (2020): 96. Tribakti: Jurnal Pemikiran Keislaman Volume 32, Nomor 1, Januari 2021
} 
Dengan semakin merebaknya biro-biro perjalanan haji-umrah dan gencarnya promosi, persaingan untuk memberikan pelayanan yang variatif, prima, nyaman serta memanjakan seakan-akan menjadikan ibadah haji dan umrah seperti layaknya orang berwisata untuk mencari penyegaran (refreshing), kesantaian (enjoying) dan kenikmatan (entertainment) atas kesibukan yang dialami. ${ }^{10}$ Inilah barangkali yang kemudian memantik orang untuk selalu melaksanakan kedua ibadah ini, karena wisata haji dan atau umrah menjadi persepsi yang dipahami oleh sebagian masyarakat sebagai sesuatu yang bukan sekedar penunaian ibadah tetapi juga bisa mendatangkan pengalaman baru, yaitu wisata religi, dimana orang dapat berwisata sekaligus mendapat pahala. Di samping tidak menutup kemungkinan ada pula motif lain yang melandasi perginya seseorang untuk melaksanakan haji/umrah tersebut selain untuk menjalankan ibadah karena panggilan Allah. Hal ini nampaknya telah mendorong minat masyarakat untuk selalu berkunjung ke baitullah, bukan karena terpenuhinya panggilan untuk melaksanakan haji atau umrah sebagai satu-satunya alasan, tetapi juga karena adanya keinginan tertentu. ${ }^{11}$

Munculnya biro-biro perjalanan haji dan umrah yang ilegal pun semakin marak. Kasus Abu Tours dan First Travel adalah contoh yang nyata, ${ }^{12}$ bagaimana para calon jamaah haji yang lelah menunggu panjang dan lamanya waktu tunggu haji atau juga karena faktor umur, biaya, waktu, dll. dengan alternatif lain untuk bisa mengganti kewajiban menunaikan rukun Islam paling pungkas ini atau juga dikarenakan alasan mengobati kerinduan sekaligus mengulang kembali “pengalaman rohani” sebelumnya bagi mereka yang sudah bergelar Haji/Hajjah dengan memilih alternatif melalui ibadah umrah ataupun sebagai sarana "pemanasan" sambil menunggu waktu pemberangkatan haji sebetulnya. ${ }^{13}$

Dalam realitas empiris peristiwa-peristiwa kooperatif dan influentatif antara agama dan ekonomi telah dibuktikan oleh penelitian Azmi dan Asnan yang menjelaskan tentang bagaimana faktor-faktor eksternal dapat mempengaruhi persepsi konsumen umrah dan haji khusus dalam memutuskan dan menggunakan jasa pada biro perjalanan

\footnotetext{
${ }^{10}$ Kiki Oktara \& Adriyan Achyar, "The Effect Of Post-Purchased Perceived-Value Toward The Relationship Quality Of Hajj And Umrah Travel Agencies In Indonesia," THE SOUTH EAST ASIAN JOURNAL OF MANAGEMENT 8, no. 1 (2014): 30.

${ }^{11}$ M. Sabiq Al Hadi, "Rekonstruksi Pemahaman Yang Keliru Tentang Kewajiban Dan Keutamaan Haji Dan Umrah," Al-Iqtishod: Jurnal Ekonomi Dan Bisnis Islam 1, no. 1 (2019).

12 detiknews, "Kasus First Travel Dan Abu Tours, Kejahatan Terencana?," 29 Mei, 2018, https://news.detik.com/kolom/d-3942896/kasus-first-travel-dan-abu-tours-kejahatan-terencana.

13 Firman Muhammad Arif, "Rancang Bangun Regulasi Penyelenggaraan Umrah Berbasis Maslahat," Jurnal Al-Daulah 8, no. 2 (2019): 170.
} 
haji dan umrah. Faktor-faktor eksternal tersebut meliputi brand equitas (keunggulan/kelebihan) dari sebuah produk, pengetahuan agama yang dimiliki pembimbing umrah dan referensi dari orang lain, kualitas dan perlakuan khusus yang ditawarkan oleh biro perjalanan haji dan umrah. ${ }^{14}$

Penelitian Nuri yang bertujuan untuk menjelaskan bagaimana perbedaan antara situasi dan kondisi haji di masa sebelum dan sesudah masa kemerdekaan. Hasilnya, ditemukan bahwa pengaturan penyelenggaraan ibadah haji pada masa pra kemerdekaan sangat kental dengan nuansa politis, tujuannya antara lain adalah untuk melindungi kepentingan penjajah, agar mereka tidak merugi sekaligus untuk mengambil hati kaum muslim. Adapun tujuan pengaturan penyelenggaraan haji pasca kemerdekaan adalah untuk melindungi dan mempermudah kaum muslim Indonesia dalam melaksanaan ibadah haji meskipun pada kenyataannya masih saja terdapat pihak-pihak yang ingin mengambil keuntungan pribadi dan kelompoknya dengan berbagai cara yang merugikan jamaah. ${ }^{15}$

Sedangkan Razaq dan Dino dalam hasil penelitiannya menyatakan bahwa melaksanakan haji dan umrah bagi seorang muslim lebih dari hanya perjalanan wisata agama tetapi adalah perjalanan ibadah yang dilandasi dasar hukum yang kuat berdasarkan perintah Tuhan (al-Quran dan Hadits) sehingga akan mendapatkan pengalaman spiritual yang luar biasa. Hal ini berbeda dengan agama lain yang menjalankan perjalanan ibadah, dia sedang beribadah sekaligus berwisata. ${ }^{16}$

Adapun penelitian Sucipto dengan menggunakan jenis kualitatif menemukan alasan-alasan yang unik terkait adanya fenomena seringnya seseorang pada kelas ekonomi menengah ke atas di kota Jambi dalam melakukan ibadah umrah dikarenakan umrah sebagai bagian infrastruktur religiusitas memiliki dimensi maslahah sekaligus good interest dalam gaya hidup kelas menengah warga kota Jambi. Umrah punya dimensi dunia dan akhirat, individu dan sosial, serta materi dan spiritual. Secara duniawi gaya hidup baru ini memang mempunyai manfaat seperti terpenuhinya kebutuhan psikis manusia seperti rasa nyaman, harga diri, memberi informasi dan pengetahuan baru. Bahkan mungkin juga dapat memberi manfaat lingkungan (intra generation) yaitu berupa adanya eksternalisasi positif dari pembelian suatu barang/jasa atau manfaat yang

14 Mohammad Savier Azmy dan Asnan Furinto, “Analisa Faktor-Faktor Yang Mempengaruhi Persepsi Konsumen Dalam Pemilihan Biro Perjalanan Umroh Dan Haji Khusus,” Journal of Business Strategy and Execution 1, no. 1 (2008): 172.

${ }^{15}$ Muhammad Nuri, "Pragmatisme Pelaksanaan Haji Di Indonesia," SALAM: Jurnal Sosial Dan Budaya Syar'i 1, no. 1 (2014).

${ }^{16}$ Razaq Raj \& Bozonelos, "Pilgrimage Experience and Consumption of Travel to the City of Makkah for Hajj Ritual," International Journal of Religious Tourism and Pilgrimage 3, no. 1 (2015).

Tribakti: Jurnal Pemikiran Keislaman

Volume 32, Nomor 1, Januari 2021 
dirasakan oleh selain pembeli pada generasi yang sama. Akan tetapi di saat yang sama, umrah menjadi kehilangan makna religiusitasnya dan menjadi identitas baru kelas menengah sebagai satu bentuk kemampuan leasure yang tidak mungkin dicapai oleh kelas miskin muslim di bawahnya. ${ }^{17}$

Beberapa penelitian diatas menggarisbawahi bahwa suatu tindakan dalam ritual agama dapat didorong oleh semangat-semangat tertentu yang bisa berupa agama, ekonomi, politik ataupun bisa pula muncul dari kondisi politis yang secara ekternal mengitarinya. Dalam situasi yang penuh dengan hiruk pikuk permasalahan yang menyelimuti penyelenggaraan ibadah umrah selama ini, baik secara eksternal maupun internal. Maka masih relevankan keberadaan biro perjalanan umrah, sebandingkah dengan service yang telah diberikannya. ${ }^{18}$ Karena dalam pelaksanaan ibadah umrah maupun haji diperlukan sebuah kerja sama dari semua pihak untuk mensukseskan ibadah tersebut. $^{19}$

Sehingga memunculkan adanya kekhawatiran masih adakah persepsi dan motif agama berakar dalam benak masyarakat muslim di tengah situasi yang menyeret mereka untuk melaksanakan ibadah umrah dengan penuh khidmat?. Dimana titik kesakralan ibadah umrah dapat mempengaruhi perilaku para pelakunya setelah selesai menjalankannya, ${ }^{20}$ ketika urusan-urusan duniawi sangat kental menyelimuti mulai dari proses dan pelaksanaannya?. Kajian ini akan menfokuskan dengan beberapa pertanyaan penelitian yang dirasa relevan guna memberikan sumbangan pemikiran dan pemahaman bagi para pengelola ibadah haji dan umrah maupun masyarakat secara umum. Penelitian ini secara umum akan mengarahkan kajiannya pada hal-hal berikut: (1) bagaimana persepsi jamaah umrah Kota Kediri tentang keberadaan biro perjalanan umrah dan pelayanan yang telah diberikannya di tengah-tengah situasi yang penuh dengan kepentingan duniawi?. (2) Motif apa saja yang mendorong jamaah umrah Kota Kediri untuk melaksanakan ibadah umrah ini?. (3) Apa saja perubahan perilaku yang terjadi pada jamaah umrah Kota Kediri setelah selesai menunaikan umrah?.

\footnotetext{
${ }^{17}$ Sucipto, "Umrah Sebagai Gaya Hidup, Eksistensi Diri Dan Komoditas Industri: Menyaksikan Perubahan Keagamaan Warga Kota,” Jurnal Kontekstualita 28, no. 1 (2013).

18 Siswanto \& Havis Haravik Achmad Irwan Hamzan, "Legal Protection For Hajj Pilgrims Through Regonal Regulation,” Mazahib: Jurnal Pemikiran Hukum Islam 17, no. 2 (2018).

${ }^{19}$ Moch Nur Ichwan, "Governing Hajj: Politics of Islamic Pilgrimage Services in Indonesia Prior to Reformasi Era,” Al-Jami'ah: Journal of Islamic Studies 46, no. 1 (2008): 126.

${ }^{20}$ Kamaruzzaman Bustamam Ahmad \& Rahmi Zakaria, "Cross-Cultural Differences Experienced during Hajj: A Case Study of Acehnese Hajj,” Studia Islamika: Indonesian Journal for Islamic Studies 25, no. 1 (2018).
} 
Penelitian ini diharapkan dapat memberikan manfaat sekaligus konstribusi positif, baik secara empiris maupun teoritis. Secara empiris, penelitian ini memberikan masukan kepada berbagai pihak: pertama, Kementerian Agama terkait dengan realitas dari praktek yang dijalankan oleh biro travel perjalanan umrah selama ini, utamanya yang terjadi di daerah-daerah yang jauh dari ibu kota dan keluh kesah yang dirasakan oleh para penggunanya. Kedua, para biro perjalanan umrah agar bisa meresapi terhadap kondisi riil yang dirasakan oleh calon jamaah umrah sehingga keberadaan biro perjalanan ini benarbenar dapat menyadari fungsinya dalam bisnis ini, karena bagaimanapun mereka telah berbinis dalam urusan agama. Dan ketiga, sebagai upaya edukasi bagi masyarakat pengguna agar fungsi kontrol terhadap sebuah regulasi benar-benar bisa berjalan optimal. Sedangkan secara teoritis, penelitian ini dapat memberikan kontribusi bagi pengembangan keilmuan sosiologi agama. Sosiologi agama sebagai ilmu yang mempelajari tentang gejala-gejala sosial yang terjadi pada masyarakat yang beragama ini menemukan medan yang lebih luas dalam perilaku keagamaan masyarakat muslim khususnya setelah usai dalam menunaikan ibadah umrah.

\section{Metode}

Penelitian ini menggunakan pendekatan kualitatif yang dimaksudkan untuk mendeskripsikan dan memahami bagaimana persepsi, motif dan perilaku jamaah umrah di tengah-tengah situasi ibadah umrah yang rentan terhadap penyelewengan, manipulasi dan penipuan. Penelitian ini merupakan kajian yang mendalam guna memperoleh data yang lengkap dan terperinci. Penelitian ini bertujuan untuk mendapatkan gambaran mendalam mengenai persepsi, motif dan perubahan perilaku jamaah umrah yang dalam hal ini obyeknya adalah perilaku manusia di suatu tempat dengan pendekatan kualitatif. ${ }^{21}$

Dari paparan mendalam tersebut peneliti akan menarik dalam suatu gambaran tentang bagaimana persepsi, motif dan perubahan perilaku jamaah umrah melalui pengamatan (observasi dan wawancara sebagai sumbangan konstruksi teori baru. Pendekatan kualitatif menurut Best, seperti yang dikutip Sukardi adalah metode penelitian yang berusaha menggambarkan dan menginterpretasikan objek sesuai dengan apa adanya. ${ }^{22}$ Jadi dengan paradigma interpretatif ini, peneliti ingin memahami (to

21 Noeng Muhadjir, Metodologi Keilmuan: Paradigma Kualitatif, Kuantitatif, Dan Mixed (Yogyakarta: Rake Sarasin, 2007): 136-149.

${ }^{22}$ Sukardi, Metode Penelitian Pendidikan: Kompetensi Dan Prakteknya (Jakarta: Bumi Aksara, 2005): 157 .

Tribakti: Jurnal Pemikiran Keislaman

Volume 32, Nomor 1, Januari 2021 
understand) dari meaning sebuah fenomena atau kasus atau gejala di lokasi tertentu. Peneliti memahami secara mendalam dan menginterpretasikan makna yang melekat pada peristiwa atau gejala tersebut, bukan menjelaskan tentang peristiwa itu.

Selain itu, guna memberikan analisis data, peneliti menggunakan teknik analitiskritis dan pengecekan data dengan triangulasi data agar data yang didapatkan benar-benar bisa dipertanggungjawabkan. ${ }^{23}$ Kegiatan analisis dilakukan dengan menelaah data, menata, membagi menjadi satuan-satuan yang dapat dikelola mensintesis, mencari pola, menemukan apa yang bermakna dan apa yang diteliti dan dilaporkan secara sistematik. Data tersebut terdiri dari deskripsi-deskripsi yang rinci mengenai situasi, peristiwa orang, interaksi, dan perilaku. Dengan kata lain, data merupakan deskripsi dari pernyataanpernyataan seseorang tentang perspektif, pengalaman, atau sesuatu hal sikap, keyakinan dan pikirannya serta petikan-petikan isi dokumen yang berkaitan dengan suatu program. ${ }^{24}$

Jenis penelitian ini menggunakan studi kasus, yaitu berusaha mendeskripsikan suatu latar, objek atau peristiwa tertentu secara rinci dan mendalam. Studi kasus adalah penelitian yang bertujuan untuk mempelajari secara intensif mengenai unit sosial tertentu, yang meliputi individu, kelompok, lembaga dan masyarakat. ${ }^{25}$ Penelitian ini akan menghasilkan informasi yang detail yang mungkin tidak bisa didapatkan pada jenis penelitian lain. Peneliti ingin mengungkapkan dan memahami secara mendalam mengenai persepsi, motif dan perubahan perilaku jamaah umrah. Penelitian ini mengambil lokasi di 2 Biro Perjalanan Umrah (KBIH salah Satu Ormas dan Biro Travel milik salah satu Pondok Pesantren) di Kota Kediri dan pada jamaah yang sudah melakukan ibadah umrah, baik yang pernah berangkat untuk pertama kalinya atau lebih melalui biro perjalan umrah di kota Kediri dan sekitarnya.

\section{Hasil dan Pembahasan}

\section{Persepsi Jamaah Umrah Kota Kediri tentang Keberadaan dan Pelayanan Biro Travel}

Dalam kenyataannya, praktik yang selama ini dilakukan oleh biro travel umrah kepada para jamaahnya berbeda-beda antara satu biro travel dengan biro travel lainnya. Hal ini pulalah yang menjadikan sering kali pengguna (jamaah umrah) berbeda persepsi dalam memberikan penilaian terhadap apa yang sudah mereka dapatkan dan yang telah

\footnotetext{
${ }^{23}$ M.Q Patton, Qualitative Evaluation Methods (London: Sage Publication, 1980).

${ }^{24}$ John W. Creswell, Qualitative Inquiry and Research Design, 3rd Ed (Los Angelos: SAGE, 2013).

${ }^{25}$ Yatim Riyanto, Metodologi Penelitian Pendidikan (Surabaya: Surabaya, 2001).
} 
dilakukan pihak biro travel umrah kepada para jamaahnya. Ada yang merasa tidak puas tetapi juga ada yang merasa puas meskipun ada kekurangan di sana-sini masih dianggap wajar dan bisa ditolelir. Akan tetapi secara umum, keberadaan biro perjalanan ibadah umrah masih sangat dibutuhkan dalam membantu jamaah untuk melaksanakan ibadah umrah. Hal ini disebabkan tidak memungkinkannya para jamaah mengurus sendiri seluruh kebutuhan-kebutuhan yang diperlukan para jamaah dalam melaksanakan ibadah umrah, mulai dari persyaratan administrasi, fasilitas transportasi dan akomodasi mulai sebelum dan sesudah umrah ataupun alasan bimbingan akan pengetahuan ibadah umrah itu sendiri. Di samping itu juga alasan tidak adanya alternatif lain, selain satu-satunya cara tersebut yang harus dilakukan guna mempercepat dan mempermudah seluruh tahapan yang harus dilalui oleh calon jamaah umrah mulai saat masih di tanah air ataupun sampai kembali lagi di tanah air.

Beberapa munculnya kekecewaan dan rasa tidak puas dikarenakan para jamaah menganggap apa yang telah dia alami dan dapatkan selama ini ternyata tidak sesuai antara promosi atau yang dijanjikan dengan kenyataannya, baik dari mulai proses pelayanan saat pendaftaran sampai kepulangan, fasilitas yang didapatkan sampai kwalitas kemampuan pengetahuan keagamaan dan profesionalisme pembimbing dan pendamping dari biro travel dalam menangani berbagai masalah yang muncul dalam pelaksanaan ibadah umrah mulai saat masih di tanah air ataupun saat sampainya di lokasi-lokasi sesuai paket program umrah tersebut. Diantara hal-hal yang dikeluhkan oleh oleh para calon jamaah umrah adalah pelayanan administratif, utamanya saat pengurusan passport atau visa perjalanan umrah, molornya waktu pemberangkatan, adanya tambahan biaya dari yang disepakati di awal dikarenakan alasan tertentu dan status PT/biro umrah itu sendiri. ${ }^{26}$

Keberadaan akan biro travel dirasakan memang sangat membantu calon jamaah guna mewujudkan cita-citanya untuk bisa melaksanakan ibadah umrah dengan penuh ketulusan, khusyuk dan tidak terlalu disibukkan dengan urusan tetek bengek sehingga diharapkan jamaah memang bisa fokus dan tenang dalam beribadah umrah. Namun di sisi lainnya, betapa rentannya calon jamaah umrah terhadap sistem dan cara yang dilakukan oleh beberapa biro travel umrah, semisal, dengan memperkerjakan orang-orang secara lepas (freelance), ketergantungan pada angkutan maskapai penerbangan dikarenakan mereka biasanya membeli tiket jauh hari guna mendapatkan harga yang miring dan atau pentingnya status biro perjalanan umrah agar dapat diketahui secara pasti oleh para calon

${ }^{26}$ Hasil Wawancara dengan Jamaah Umrah Kota Kediri. 
jamaah, apakah biro tersebut memang cabang resmi dari sebuah biro umrah yang telah mendapatkan izin dari lembaga terkait (dalam hal ini Kemenag Pusat) atau memang hanya sub yang tidak memiliki keterikatan/bukan cabang resmi tetapi hanya berdasarkan kesepakatan tertulis yang mengatur kesanggupan target penyetoran calon jamaah oleh PT/biro travel dari sub tersebut dalam jangka waktu tertentu dikarenakan alasan-alasan bisnis semata.

Dari penjelasan di atas diketahui bahwa bisnis perjalanan ibadah umrah selama ini memang memiliki celah menimbulkan persepsi negatif di mata para konsumen/jamaah umrah. Meskipun terkadang persepsi negatif ini muncul bukan karena disebabkan oleh kesalahan dari biro travel dikarenakan dalam bisnis ini juga sangat tergantung dan ditentukan oleh pihak lain, yaitu maskapai penerbangan yang karena pada kasus-kasus tertentu biro travel pun tidak akan bisa berbuat apapun, di samping pihak travel pun juga tidak mau merugi.

Haji ataupun umrah oleh sebagian besar masyarakat Kota Kediri dipahami murni sebagai sebuah bentuk panggilan ibadah yang harus diikhtiari dan diusahakan oleh siapapun yang mengaku dirinya muslim dan dirinya telah mampu. Kesadaran akan hal tersebut didasarkan pada salah satu dari rukun Islam serta dilandasi oleh perwujudan dari pengakuan akan adanya Dzat Yang Maha Kuasa oleh sang makhluk dan sebagai bentuk wujud terima kasih atas segala nikmat dan rezeki yang telah dititipkan oleh-Nya kepada mereka. Oleh karenanya dengan melaksanakan umrah di tanah asal munculnya Agama Islam dan tempat kelahiran Rasulullah dan nenek moyangnya, yaitu Nabi Ibrahim mereka meyakini bahwa mereka akan mendapatkan keberkahan hidup dan lebih meresapi akan makna sesungguhnya dari arti “ibadah" itu sendiri dan kehidupan selanjutnya.

Keberadaan sebuah persepsi terhadap sesuatu tentu tidak muncul dan hadir begitu saja atau berasal dari ruang kosong dan hampa. Akan tetapi kemunculannya sangat dipengaruhi oleh sebab-sebab tertentu. Baik yang dikarenakan oleh sebab yang berasal dari subyek ataupun obyek itu sendiri. Akan tetapi keduanya (subyek dan obyek) tersebut juga sangat dipengaruhi oleh faktor-faktor internal dan eksternal sehingga memunculkan persepsi yang bisa jadi berbeda-beda. Andaikan muncul persepsi yang sama terhadap sesuatu akan tetapi setidak-tidaknya alasan-alasan yang disampaikan juga akan berbedabeda atau tidak ada yang sama persis. Kondisi inilah yang digambarkan oleh Schiffman dan Kanuk yang mendefinisikan persepsi sebagai sebuah proses yang dilakukan individu 
untuk memilih, mengatur, dan menafsir stimuli berdasarkan kebutuhan, nilai-nilai dan harapan setiap individu itu sendiri. ${ }^{27}$

Hal demikian ini juga berlaku bagi jamaah umrah di Kota Kediri yang memberikan persepsi tentang keberadaan biro perjalanan umrah dan pelayanan yang telah diberikannya. Hasil dari persepsi jamaah umrah Kota Kediri tentang keberadaan biro perjalanan umrah yang menyatakan bahwa keberadaanya masih sangat dibutuhkan, akan tetapi alasan-alasan tentang hal tersebut sangat beragam. Ada yang menyatakan bahwa keberadaan biro umrah memang dirasa sangat bisa membantu kepada calon jamaah umrah dalam melaksanakan ibadah dikarenakan jamaah tidak ribet dalam urusan administratif, transportasi dan akomodasi ataupun tersedia tenaga ahlinya. ${ }^{28}$

Hasil persepsi yang menyatakan bahwa keberadaan biro travel umrah masih sangat dibutuhkan setidaknya sampai sekarang dikarenakan keberadaanya justru membantu calon jamaah agar tidak ribet dalam mengurusi syarat-syarat administratif, sarana dan akomodasi ataupun lain-lainnya. Atau jika tidak demikian, alasan lain yang menjelaskan bahwa keberadaannya tetap diperlukan meski dengan memberikan beberapa catatan, adalah membuktikan jika hasil persepsi sang subyek (jamaah umrah) sangat dipengaruhi oleh faktor internal dan eksternal yang melingkupi para jamaah itu sendiri. Hal ini sejalan dengan pendapat Ristiyanti dan Ihalauw ${ }^{29}$ yang menyatakan bahwa terdapat faktor internal dan eksternal yang mempengaruhi terbentuknya persepsi.

Meskipun demikian, hasil penelitian juga sekaligus dapat diketahui bahwa faktorfaktor internal (pengalaman, kebutuhan saat itu, nilai-nilai yang dianut dan harapan yang melingkupi) lebih memberikan pengaruh daripada faktor-faktor eksternal (stimulus dan situasi lingkungan sosial) terhadap hasil persepsi tentang keberadaan biro perjalanan umrah tersebut. ${ }^{30}$ Hal ini dapat dilihat, semisal dari pernyataan informan yang menyatakan bahwa keberadaan biro travel umrah tetap dibutuhkan karena alasan adanya kedekatan emosional dengan para pengelolanya yang disebabkan mempunyai kesamaan dalam sejarahnya (pengalaman). ${ }^{31}$ Atau juga peryataan informan yang meskipun pernah

${ }^{27}$ Leon G Schiffman \& Leslies Kazar Kanuk, Perilaku Konsumen (Jakarta: PT. Macanan Jaya Cemerlang, 2011): 137.

${ }^{28}$ Hasil Wawancara dengan Jamaah Umrah Kota Kediri.

${ }^{29}$ Ristiyanti Prasetijo \& Jhon J.O.L Ihalauw, Perilaku Konsumen (Yogyakarta: Andi Yogyakarta, 2004): 67-70.

${ }^{30}$ Hasil Wawancara dengan Jamaah Umrah Kota Kediri.

${ }^{31}$ Wawancara dengan AH. Pengelola Biro Travel dan Umrah Salah Satu ORMAS Kota Kediri.

Tribakti: Jurnal Pemikiran Keislaman

Volume 32, Nomor 1, Januari 2021 
pendapatkan kekecewaan tapi dengan adanya biro travel dia merasa telah terbantu dalam urusan administratif, akomodasi, transportasi dan bimbingan ibadahnya. ${ }^{32}$

Adapun hasil persepsi jamaah umrah tentang pelayanan yang telah diberikan biro umrah yang menyatakan bahwa sebagian jamaah merasa puas dan sebagian tidak puas dapat dipahami adalah sebagai akibat dari pengaruh gabungan antara seluruh faktor internal dan sebagian faktor eksternal dalam memunculkan persepsi tersebut. Seluruh faktor internal yang dimaksud adalah meliputi: pengalaman, kebutuhan saat itu, nilai-nilai yang dianut dan harapan yang melingkupi. Sedangkan sebagian dari faktor eksternal yang di maksud adalah stimulus dan faktor budaya.

Hal ini bisa dibuktikan dengan melihat kembali hasil informasi yang telah didapat dan dijelaskan. Semisal, munculnya kekecewaan jamaah atas pelayanan yang telah diberikan biro travel ternyata tidak sesuai dengan yang dijanjikan dan adanya informasi yang berubah-ubah atau alasan munculnya kepuasan jamaah atas pelayanan yang telah diberikan biro travel umrah karena beberapa alasan, semuanya di sebabkan oleh faktor internal: pengalaman, yang telah dialami jamaah ${ }^{33}$, kebutuhan saat $i^{34}{ }^{34}$, nilai-nilai yang dianutnya ${ }^{35}$ dan ekspektasi (harapan) ${ }^{36}$ serta pengaruh faktor eksternal: stimulus ${ }^{37}$.

Semua hasil temuan di atas berlawanan dengan hasil penelitian yang dilakukan oleh Azmi dan Asnan yang menjelaskan tentang bagaimana faktor-faktor eksternal dapat mempengaruhi persepsi konsumen umrah dan haji khusus dalam memutuskan dan menggunakan jasa pada biro perjalanan haji dan umrah. Faktor-faktor eksternal tersebut meliputi brand equitas (keunggulan/kelebihan) dari sebuah produk, pengetahuan agama yang dimiliki pembimbing umrah dan referensi dari orang lain, kualitas dan perlakuan khusus yang ditawarkan oleh biro perjalanan haji dan umrah. ${ }^{38}$

Akan tetapi hasil penelitan ini mendukung hasil penelitian Nuri yang menyatakan bahwa tujuan pengaturan penyelenggaraan haji pasca kemerdekaan adalah untuk melindungi dan mempermudah kaum muslim Indonesia dalam melaksanaan ibadah haji meskipun pada kenyataannya masih saja terdapat pihak-pihak yang ingin mengambil

\footnotetext{
${ }^{32}$ Wawancara dengan YWH. Jamaah Umrah Kota Kediri.

${ }^{33}$ Hasil Wawancara dengan Jamaah Umrah Kota Kediri.

${ }^{34}$ Hasil Wawancara dengan Jamaah Umrah Kota Kediri.

${ }^{35}$ Wawancara dengan MQ. Jamaah Umrah Kota Kediri.

${ }^{36}$ Wawancara dengan MM. Jamaah Umrah Kota Kediri.

${ }^{37}$ Hasil Wawancara dengan Jamaah Umrah Kota Kediri.

38 Mohammad Savier Azmy dan Asnan Furinto, "Analisa Faktor-Faktor Yang Mempengaruhi Persepsi Konsumen Dalam Pemilihan Biro Perjalanan Umroh Dan Haji Khusus.” 
keuntungan pribadi dan kelompoknya dengan berbagai cara yang merugikan jamaah meskipun obyek penelitiannya berbeda. ${ }^{39}$

Secara umum persepsi jamaah umrah Kota Kediri mengenai keberadaan dan pelayanan biro travel dan umrah memiliki relevansi dengan penelitian-penelitian terdahulu. Artinya persepsi jamaah umrah Kota Kediri mengenai keberadaan dan pelayanan biro travel dipengaruhi oleh beberapa faktor. Sehingga ketika faktornya berbeda maka persepsi dari masing-masing jamaah juga berbeda. Seperti juga hasil penelitian Azmi dan Asnan yang menyebutkan bahwa faktor-faktor eksternal memberikan pengaruh dalam persepsi konsumen jamaah umrah dan haji. Sementara penelitian Nuri mengatakan bahwa guna memberikan persepsi baik dari para jamaah haji dan umrah, maka pengaturan penyelenggaraan haji dan umrah ditujukan untuk memberikan kenyamanan dan perlindungan kepada jamaah.

\section{Motif Jamaah Umrah Kota Kediri untuk Melaksanakan Ibadah Umrah}

Terdapat beberapa motif dalam diri para jamaah umrah di Kota Kediri dalam melaksanakan ibadah umrah. Hal ini bisa jadi sangat dipengaruhi oleh perbedaanperbedaan dalam diri satu jamaah dengan jamaah lainnya, baik dikarenakan faktor internal ataupun eksternal. Berdasarkan semua hasil wawancara dapat disimpulkan bahwa masih terdapat diantara jamaah umrah yang mempunyai motif dalam melaksanakan umrah sebagai sebuah ibadah di tengah carut marutnya sistem dan pelaksanaan ibadah itu sendiri, meskipun dengan segala varian dari arti ibadah itu sendiri.

Haji ataupun umrah oleh sebagian besar masyarakat Kota Kediri dipahami murni sebagai sebuah bentuk panggilan ibadah yang harus diikhtiari dan diusahakan oleh siapapun yang mengaku dirinya muslim dan dirinya telah mampu. Kesadaran akan hal tersebut didasarkan pada salah satu dari rukun Islam serta dilandasi oleh perwujudan dari pengakuan akan adanya Dzat Yang Maha Kuasa oleh sang makhluk dan sebagai bentuk wujud terima kasih atas segala nikmat dan rezki yang telah dititipkan olehNya kepada mereka. Oleh karenanya dengan melaksanakan umrah di tanah asal munculnya Agama Islam dan tempat kelahiran Rasulullah dan nenek moyangnya, yaitu Nabi Ibrahim mereka meyakini bahwa mereka akan mendapatkan keberkahan hidup dan lebih meresapi akan makna sesungguhnya dari arti “ibadah" itu sendiri dan kehidupan selanjutnya.

${ }^{39}$ Muhammad Nuri, "Pragmatisme Pelaksanaan Haji Di Indonesia."

Tribakti: Jurnal Pemikiran Keislaman

Volume 32, Nomor 1, Januari 2021 
Selain murni karena niat ibadah ternyata diketahui pula adanya percampuran motif dalam melaksanakan umrah dengan motif lainnya selain diniatkan hanya untuk ibadah pada jamaah umrah Kota Kediri. Dari beberapa penjelasan dan pengakuan dapat disimpulkan bahwa memang terdapat adanya percampuran antara motif ibadah dengan motif lain yang berbeda-beda dalam diri jamaah saat melaksanakan umrah. Dari hasil penelitian ini didapatkan bahwa terdapat dua motif masyarakat Kota Kediri dalam melaksanakan ibadah umrah. Pertama, masyarakat Kota Kediri melaksanakan umrah memang mempunyai motif murni untuk melaksanakan ibadah dan yang kedua, motif ibadah tetapi bercampur dengan motif lainnya.

Motif $^{40}$ yang diartikan sebagai suatu set yang dapat atau mudah menyebabkan individu untuk melakukan kegiatan-kegiatan tertentu (berbuat sesuatu) dan untuk mencapai tujuan-tujuan tertentu atau keadaan yang terdapat dalam diri seseorang yang mendorongnya untuk melakukan aktivitas tertentu guna pencapaian suatu tujuan sangatlah mempengaruhi terhadap motif seseorang melaksanakan sebuah tindakan, ${ }^{41}$ termasuk juga tindakan dalam melaksanakan ritual keagamaan. Dampak dengan adanya sebuah motif juga diyakini akan dapat mempengaruhi terhadap pilihan-pilihan tindakan ataupun perbuatan yang muncul sesudahnya sebagai hubungan sebab-akibat. Sebagai contoh, karena seseorang memiliki motif melaksanakan umrah memang adalah untuk ibadah maka pelaku akan berusaha sekuat mungkin dapat dan mampu menjalankannya dengan tidak mengotorinya dengan hal-hal yang dapat merusak kesucian dari ibadah tersebut sehingga tujuan yang diharapkan dari ibadah tersebut dapat tercapai.

Hasil penelitian ini menunjukkan bahwa jamaah umrah Kota Kediri yang melaksanakan umrah dengan motif murni ibadah, diketahui karena munculnya kesadaran pelaku atas adanya panggilan Allah, ${ }^{42}$ tunduknya hamba terhadap semua perintahNya ${ }^{43}$ ataupun sikap ta'abuddiyyah ${ }^{44}$ (kepasrahan). Penggolongan ini juga menunjukkan bahwa terdapat kesesuaian fakta tersebut dengan teori psikologi agama yang merujuk kepada adanya motif teogenetis, dalam artian manusia memerlukan interaksi dengan tuhannya untuk dapat menyadari akan tugasnya sebagai manusia yang berketuhanan. ${ }^{45}$

\footnotetext{
${ }^{40}$ Alex Sobur, Psikologi Umum (Bandung: CV Pustaka Setia, 2003): 267.

${ }^{41}$ Djaali, Psikologi Pendidikan (Jakarta: PT Bumi Aksara, 2011): 101.

${ }^{42}$ Wawancara dengan AH. Pengelola Biro Travel dan Umrah Kota Kediri.

${ }^{43}$ Wawancara dengan HIT. Jamaah Umrah Kota Kediri.

${ }^{44}$ Wawancara dengan MQ. Jamaah Umrah Kota Kediri.

${ }^{45}$ Faizah, Psikologi Dakwah (Jakarta: PRENADAMEDIA GROUP, 2006): 114.
} 
Kedalaman akan makna, pemahaman ataupun bentuk perwujudan dari interaksi manusia ataupun hamba kepada Sang Pencipta ini sangat dipengaruhi oleh adanya teori dalam psikologi, tepatnya adalah kebutuhan terhadap motif beragama. Motif ini diyakini mampu menyelamatkan diri seorang hamba dari bentuk ancaman ataupun siksaan yang telah dijanjikan oleh Sang Khaliknya sehingga pelaku merasa mendapatkan ketentraman dalam hatinya.

Adapun penggolongan jamaah umrah Kota Kediri yang melaksanakan umrah dengan motif ganda atau bercampurnya antara motif ibadah dengan motif lainnya dikarenakan alasan bahwa beribadah umrah karena dorongan untuk berbakti kepada orang tua ${ }^{46}$, pelarian diri dari urusan-urusan duniawi ${ }^{47}$ ataupun karena persiapan sebelum melaksanakan ibadah haji ${ }^{48}$ menunjukkan bercampurnya antara motif agama dengan motif fisiologis dalam satu tindakan keagamaan. Kedua motif tersebut muncul secara beriringan, bisa jadi muncul dikarenakan adanya dua kepentingan yang memang dibutuhkan oleh semua manusia, baik kepentingan jasmani ataupun juga rohani sehingga sisi "manusia" si pelaku muncul secara bersamaan.

Kedua motif yang didapatkan dalam penelitian ini sekaligus membenarkan terhadap hasil penelitian yang telah dilakukan baik oleh Nuki yang menyatakan bahwa melaksanakan umrah adalah sebagai upaya alternatif yang didasarkan pada terdapatnya banyaknya permasalahan dalam sistem penyelenggaraan ibadah haji, utamanya terkait dengan lamanya masa tunggu dalam sistem haji sekaligus mereka dapat berbelanja berbagai barang, meskipun demikian, masih tersirat alasan utama mereka melaksanakan umrah berulang-ulang adalah dikarenakan adanya panggilan Allah. ${ }^{49}$ Hasil ini juga mendukung penelitian Kristel Kressler yang menyatakan bahwa umrah bagi seorang muslim bukan hanya perupakan perjalanan ritual keagamaan namun sebagai peluang yang besar untuk mengenalkan wisata halal ke seluruh dunia terutama ke negara-negara yang notabene masyarakatnya beragama selain Islam. ${ }^{50}$

Secara umum motif jamaah umrah Kota Kediri dalam melaksanakan ibadah umrah dipengaruhi oleh beberapa hal. Relevansi hasil penelitian mengenai motif jamaah umrah Kota Kediri dalam melaksanakan ibadah umrah ini memiliki hubungan dengan

\footnotetext{
${ }^{46}$ Wawancara dengan YWH. Jamaah Umrah Kota Kediri.

${ }^{47}$ Wawancara dengan U dan MM. Jamaah Umrah Kota Kediri.

${ }^{48}$ Wawancara dengan U. Jamaah Umrah Kota Kediri.

${ }^{49}$ Nuki Mayasari, Recharging Fairh: The Practice of Multiple Umrah Trips among Middle Class in Yogyakarta (Perpustakaan Pusat UGM: Tesis CRCS UGM, 2014).

${ }^{50}$ Kristel Kessler, "Conceptualizing Mosque Tourism: A Central Feature of Islamic and Religious Tourism," International Journal of Religious Tourism And Pilgrimage 3, no. 2 (2015).

Tribakti: Jurnal Pemikiran Keislaman

Volume 32, Nomor 1, Januari 2021
} 
penelitian-penelitian terdahulu. Dimana Nuki dan Kressler menemukan bahwa selain aspek ibadah, melaksanakan ibadah umrah juga dipengaruhi oleh motif-motif yang lain. Dimana salah satu motifnya tentu juga dipengaruhi oleh pelayanan dan fasilitas yang diberikan oleh biro travel haji dan umrah.

\section{Perubahan Perilaku Jamaah Umrah Kota Kediri}

Dalam sebuah amal perbuatan diyakini akan memberikan dampak bagi sang pelakunya, akan tetapi kelanggengan buah atau dampak dari amal tersebut tentu diyakini juga bisa berbeda-beda antara satu orang dengan orang lainnya meskipun perbuatan yang telah dilakukan itu adalah sama, baik dari sisi waktu ataupun wujud perubahan perilaku yang muncul akibat dari dampak itu sendiri.

Hal yang demikian (perubahan perilaku dan lama waktunya) juga berlaku dalam ibadah umrah. Bagi seseorang yang telah melaksanakan ibadah umrah, efek atau dampak yang ditimbulkan juga sangat berbeda antara jamaah satu dengan lainnya karena sangat dipengaruhi oleh faktor internal dan eksternal yang melingkupi diri si pelaku baik saat sebelum, saat pelaksanaan dan sesudah si pelaku melaksanakan ibadah umrah tersebut.

Ibadah umrah ataupun haji dalam pandangan Islam adalah dipahami sebagai bentuk panggilan Allah kepada orang yang dipilihNya. Oleh karenanya, bagi si pelaku yang merasa dipanggil, mereka yang terpilih wajib memenuhi panggilan tersebut serta berusaha untuk memahami makna dan arti dari panggilan tersebut yang kemudian diwujudkan dalam tindakan dan perilaku si pelaku.

Dari hasil wawancara dapat diketahui bahwa setelah melaksanakan ibadah umrah, beberapa jamaah umrah mengalami perubahan perilaku yang lebih baik dari sebelumnya, mulai dari ucapan, sikap, cara berpikir dan bertindak ataupun juga ibadahnya. Perubahanperubahan tersebut menurut informasi yang didapat, terjadi karena salah satunya disebabkan dia mengalami peristiwa batin yang sangat membekas di hatinya yang dia dapatkan saat melaksanakan ibadah umrah dan jamaah tersebut berusaha selalu menjaganya di setiap waktu dengan berbagai cara.

Meskipun diyakini bahwa setiap selesainya ibadah dikerjakan dapat memberikan dampak bagi para pelakunya, akan tetapi dampak yang muncul tersebut ternyata bisa jadi berbeda-beda dan andaikan dampak yang muncul tersebut adalah sama akan tetapi bisa jadi durasinya berbeda-beda antara satu jamaah umrah satu dengan lainnya. Hal ini juga terjadi di jamaah umrah Kota Kediri. 
Hasil wawancara menunjukkan bahwa perubahan-perubahan perilaku yang baik dan muncul serta dialami oleh jamaah sebagai "buah" dari melaksanakan umrah bisa saja memang bersifat temporary, tidak melekat dan bersifat lama. Hal ini salah satunya diakibatkan oleh kembalinya kesibukan dan rutinitas para jamaah dalam bekerja atau berakitivitas sebagaimana sebelum melaksanakan ibadah umrah.

Hasil wawancara juga menemukan bahwa memang perubahan-perubahan perilaku dan durasi lamanya merasakan hasil yang didapat dan dialami setelah selesainya ibadah umrah antara satu jamaah dengan jamaah lainnya memang berbeda-beda karena sangat dipengaruhi banyak hal. Diantaranya adalah cara pandang dan penempatan terhadap suatu makna yang berbeda-beda. Ada yang memberikan makna sempit tapi juga ada yang luas.

Hasil wawancara ini juga menunjukkan bahwa terdapat perubahan perilaku yang dialami oleh warga Kota Kediri yang telah kembali ke kampung halamannya setelah selesai menjalankan ibadah umrah. Perubahan perilaku tersebut dapat digolongkan ke dalam dua jenis. Pertama, memberikan dampak perubahan yang lebih baik dari sebelumnya terhadap perilaku jamaah dan bersifat lama waktunya. Kedua, memberikan dampak perubahan terhadap perilaku jamaah tetapi sifatnya hanya sementara waktu. Kedua jenis perubahan perilaku ini dapat dipahami sebagai "buah" atau ganjaran dari rampungnya sebuah ritual keagamaan yang telah dijalankan si pelakunya.

Meskipun sama-sama memberikan dampak bagi para pelakunya, akan tetapi sifat kelanggengan/lamanya waktu dari merasakannya "buah" ini antara dua kelompok tersebut berbeda. ${ }^{51}$ Perbedaan ini jika dirunut kembali dengan merujuk pada hasil fokus penelitian sebelumnya, dapat diketahui bahwa terdapat hubungan dari rangkaian akibat motif dan pengalaman batin yang dimiliki dan dirasakan oleh si pelaku yang yang tidak sama persis saat menjalani proses ibadah tersebut. Dimana pengalaman batin juga sangat dipengaruhi oleh adanya pengalaman-pengalaman sebelumnya utamanya terkait dengan pengalaman keagamaan, pendidikan, sosial lingkungan. Dengan demikian, hal ini sejalan dengan pandangan Alport, sebagaimana yang dikutip Jalaluddin Rahmat yang mendefinisikan perilaku sebagai hasil belajar yang diperoleh melalui pengalaman dan interaksi yang terus menerus dengan lingkungan. Dengan seringnya berada dalam suatu

${ }^{51}$ Teori insentif (incentive theory) menyatakan bahwa perilaku organisme itu disebabkan karena adanya insentif. Dengan insentif akan mendorong organisme berbuat atau berperilaku. Insentif atau juga disebut sebagai reinforcement ada yang positif dan ada yang negatif. Reinforcement yang positif adalah berkaitan dengan hadiah, sedangkan reinforcement yang negatif berkaitan dengan hukuman. Reinforcement yang positif akan mendorong organisme dalam berbuat, sedangkan reinforcement yang negatif akan dapat menghambat dalam organisme berperilaku

Tribakti: Jurnal Pemikiran Keislaman

Volume 32, Nomor 1, Januari 2021 
lingkungan, akan menjadikan seseorang dapat menentukan suatu sikap karena disadari atau tidak, perilaku tersebut tercipta karena pengalaman yang dialaminya. Sehingga sikap atau berubah perilaku seseorang tidak muncul dengan sendirinya, akan tetapi ia merupakan hasil dari penafsiran dari banyak hal dan sikap atau tingkah laku ini juga bisa menjadi indikator dari sempurna atau tidaknya akan perilaku tersebut. ${ }^{52}$

Adapun penyebab lama tidaknya hasil dari perubahan perilaku yang melekat pada diri para jamaah sebagai akibat dan buah dari mereka menunaikan ibadah umrah dapat dijelaskan dengan menggunakan teori atribusi ${ }^{53}$ dimana hasil dari wawancara dengan beberapa informan yang berubah perilakunya menjadi lebih baik dari sebelum melaksanakan ibadah umrah akan tetapi durasinya tidak lama/sesaat diakibatkan oleh situasi dan lingkungan yang berada di sekeliling si pelaku. ${ }^{54}$

Hasil ini juga sekaligus membenarkan pendapat yang disampaikan Durkheim bahwa agama merupakan perwujudan dari collective consciousness (kesadaran kolektif) sekalipun selalu ada perwujudaan-perwujudan lainnya. Tuhan dianggap sebagai simbol dari masyarakat itu sendiri yang sebagai collective consciouness kemudian menjelma ke dalam collective representation. Tuhan itu hanyalah idealisme dari masyarakat itu sendiri yang menganggapnya sebagai makhluk yang paling sempurna (Tuhan adalah personifikasi masyarakat) dan melebihi apa yang dimiliki oleh manusia. Dalam hal ini Durkheim mengemukakan dua hal pokok dalam agama yaitu kepercayaan dan ritus/ upacara-upacara. Keyakinan adalah pikiran dan ritus adalah tindakan sehingga agama merupakan lambang collective representation dalam bentuknya yang ideal. Agama adalah sarana untuk memperkuat kesadaran kolektif seperti ritus-ritus agama. Orang yang terlibat dalam upacara keagamaan maka kesadaran mereka tentang collective consciouness semakin bertambah kuat. Sesudah upacara keagamaan suasana keagamaaan dibawa dalam kehidupan sehari-hari, kemudian lambat laun collective consciousness tersebut semakin lemah kembali. Jadi ritual-ritual keagamaan merupakan sarana yang dianggap berperan dalam menciptakan kesadaran kolektif di antara masyarakat, atau

52 Jalaluddin Rahmat, Psikologi Agama (Jakarta: Raja Grafindo, 2002): 201.

${ }^{53}$ Atribusi adalah memperkirakan apa yang menyebabkan orang lain itu berperilaku tertentu. Menurut Heider, setiap individu pada dasarnya adalah seseorang ilmuwan semu (pseudo scientist) yang berusaha untuk mengerti tingkah laku orang lain dengan mengumpulkan dan memadukan potonganpotongan informasi sampai mereka tiba pada sebuah penjelasan masuk akal tentang sebab-sebab orang lain bertingkah laku tertentu.

${ }^{54}$ Hasil Wwancara dengan Jamaah Umrah Kota Kediri. 
dengan kata lain ritual agama merupakan charge bagi manusia untuk mendekatkan diri kembali kepada Tuhannya. ${ }^{55}$

Hasil ini juga mendukung teori Geertz yang menyatakan bahwa agama sebagai suatu sistem kebudayaan, satu sistem yang bertujuan untuk menciptakan perasaan dan motivasi yang kuat, mudah menyebar, dan tidak mudah hilang dalam diri seseorang dengan cara membentuk konsepsi tentang sebuah tatanan eksistensi dan meletakan konsepsi ini kepada pancaran-pancaran faktual dan pada akhirnya perasaan dan motivasi ini akan terlihat sebagai realitas yang unik. Simbol tersebut akan tertanam dalam individu secara privasi namun bisa juga simbol-simbol tersebut terlepaskan dari individu. Lalu perasaan dan motivasi tersebut tertanam kuat dan tidak mudah hilang dan inilah yang disebut Geertz bahwa agama menyebabkan seseorang merasakan dan melakukan sesuatu. ${ }^{56}$ Dalam pandangan Durkheim dan Geertz, agama diyakini dapat memberikan pengaruh terhadap para pengikutnya dan pengaruh tersebut dapat terbawa dan dirasakan dalam kehidupan pelakunya.

Hasil penelitian ini juga bertentangan dengan hasil thesis Akeel yang menyatakan bahwa "banyak" dari para jamaah haji, setelah mereka selesai menunaikan ibadah hajinya, ternyata tidak memberikan dampak dalam diri jamaah dikarenakan mereka tidak mendapatkan dan mengalami langsung pengalaman spiritual selama menunaikan ibadah tersebut. ${ }^{57}$ Adapun hasil dari penelitian ini justru menunjukkan hal sebaliknya, dimana ibadah umrah justru memberikan dampak positif bagi perilaku jamaah Kota Kediri meskipun sifat waktunya atau durasi dari dampak perilaku tersebut di ketahui ada yang lama dan ada pula yang hanya bersifat sementara waktu saja.

Perubahan pelaku para jamaah umrah di Kota Kediri secara umum ternyata memiliki sebuah dampak yang sangat signifikan. Sehingga relevansi dari hasil ini secara langsung menguatkan dan bahkan menentangnya, dimana perubahan perilaku para jamaah setelah melakukan ibadah umrah maupun haji mengalami sebuah perubahan meskipun kadar waktunya berbeda. Perubahan perilaku ini tentu juga memiliki keterikatan dengan persepsi dan motif dalam melaksakana ibadah umrah maupun haji melalui biro haji dan umrah dan berbagai layanan oleh pemerintah Indonesia.

55 Daniel L. Pals, Seven Theories of Religion: Tujuh Teori Agama Paling Komprehensif (Yogyakarta: IRCISOD, 2012): 162.

${ }^{56}$ Clifford Gertz, Agama Jawa: Abangan, Santri, Priyayi Dalam Kebudayaan Jawa, Terj. Aswab Mahasin (Jakarta: Komunitas Bambu, 2013).

${ }^{57}$ Akeel Ibrahim al-Ken, The Hajj: Past, Present, and Future: The Communication Aspect (Leeds: The University of Leeds: Doctoral Disertation, 1995).

Tribakti: Jurnal Pemikiran Keislaman

Volume 32, Nomor 1, Januari 2021 


\section{Kesimpulan}

Dari hasil penelitian yang telah dilakukan terkait persepsi, motif dan perubahan perilaku jamaah umrah Kota Kediri, di ketahui bahwa persepsi jamaah umrah terhadap keberadaan biro travel perjalanan umrah dirasakan masih sangat dibutuhkan saat ini dikarenakan keberadaannya sangat membantu guna mempermudah proses pelaksanaan ibadah umrah itu sendiri. Meskipun demikian, terdapat sebagian jamaah umrah merasakan ketidakpuasan terhadap layanan yang telah diberikan biro travel perjalanan umrah sedangkan sebagian yang lain merasakan adanya kepuasan. Sementar itu terkait dengan motif jamaah umra Kota Kediri terdapat dua motif yang berbeda dalam menunaikan ibadah umrah dalam diri jamaah umrah. Ada yang mempunyai motif murni untuk melaksanakan ibadah tetapi ada pula motif beribadah yang bercampur dengan motif lainnya. Sedangkan berkaitan dengan perubahan perilaku jamaah umrah Kota Kediri, ibadah umrah memberikan dampak kepada perilaku yang lebih baik dari sebelumnya bagi pelakunya. Hanya saja durasinya berbeda-beda, terdapat yang berdurasi lama dan ada juga yang bersifat sementara.

\section{Daftar Pustaka}

Achmad Irwan Hamzan, Siswanto \& Havis Haravik. "Legal Protection For Hajj Pilgrims Through Regonal Regulation." Mazahib: Jurnal Pemikiran Hukum Islam 17, no. 2 (2018).

Ahmad, Kamaruzzaman Bustamam \& Zakaria, Rahmi. "Cross-Cultural Differences Experienced during Hajj: A Case Study of Acehnese Hajj." Studia Islamika: Indonesian Journal for Islamic Studies 25, no. 1 (2018).

al-Hadi, M. Sabiq. "Rekonstruksi Pemahaman Yang Keliru Tentang Kewajiban Dan Keutamaan Haji Dan Umrah.” Al-Iqtishod: Jurnal Ekonomi Dan Bisnis Islam 1, no. 1 (2019).

al-Ken, Akeel Ibrahim. The Hajj: Past, Present, and Future: The Communication Aspect. Leeds: The University of Leeds: Doctoral Disertation, 1995.

Anwar, Syaiful \& Hilpiah, Dida. "Perancangan Aplikasi Pendaftaran Umrah Berbasis Web Pada Nurrahma Tour \& Travel." INTI NUSA MANDIRI 15, no. 1 (2020).

Arif, Firman Muhammad. "Rancang Bangun Regulasi Penyelenggaraan Umrah Berbasis Maslahat.” Jurnal Al-Daulah 8, no. 2 (2019): 170.

Azmy, Mohammad Savier dan Furinto, Asnan. “Analisa Faktor-Faktor Yang Mempengaruhi Persepsi Konsumen Dalam Pemilihan Biro Perjalanan Umrah Dan Haji Khusus.” Journal of Business Strategy and Execution 1, no. 1 (2008): 172. 
Creswell, John W.. Qualitative Inquiry and Research Design, 3rd Ed. Los Angelos: SAGE, 2013.

Muneeza, Aishathet al. "A Comparative Study of Hajj Fund Management Institutions in Malaysia, Indonesia and Maldives." International Centre for Education in Islamic Finance (INCEIF) 5, no. 3 (2018).

Dani, Akhmad Anwar. "Problematika Pengelolaan Penyelenggaraan Umrah Di Kota Surakarta." Ilmu Dakwah: Academic Journal for Homiletic Studies 12, no. 1 (2018): 24.

detiknews. "Kasus First Travel Dan Abu Tours, Kejahatan Terencana?" 29 Mei, 2018. https://news.detik.com/kolom/d-3942896/kasus-first-travel-dan-abu-tourskejahatan-terencana.

Djaali. Psikologi Pendidikan. Jakarta: PT Bumi Aksara, 2011.

Fadilah, Lia. "Strategi Dan Manajemen Travel Haji Dan Umrah: Studi Analisis Persaingan Travel Haji Dan Umrah Kota Medan Dalam Pelayanan Dan Kualitas Untuk Meningkatkan Jumlah Konsumen." Al-Muamalat: Jurnal Hukum Ekonomi Syariah IV, no. 1 (2019): 3.

Faizah. Psikologi Dakwah. Jakarta: PRENADAMEDIA GROUP, 2006.

Gertz, Clifford. Agama Jawa: Abangan, Santri, Priyayi Dalam Kebudayaan Jawa, Terj. Aswab Mahasin. Jakarta: Komunitas Bambu, 2013.

Ichwan, Moch Nur. "Governing Hajj: Politics of Islamic Pilgrimage Services in Indonesia Prior to Reformasi Era." Al-Jami'ah: Journal of Islamic Studies 46, no. 1 (2008): 126.

Japeri. "Pengaruh Kuota Terhadap Daftar Tunggu Naik Haji Di Kota Padang." JEBI: Jurnal Ekonomi Dan Bisnis Islam 2, no. 1 (2017).

Kessler, Kristel. "Conceptualizing Mosque Tourism: A Central Feature of Islamic and Religious Tourism." International Journal of Religious Tourism And Pilgrimage 3, no. 2 (2015).

Kisworo, Budi. "Ibadah Haji Ditinjau Dari Berbagai Aspek.” Al Istinbath : Jurnal Hukum Islam 2, no. 1 (2017).

Mayasari, Nuki. Recharging Fairh: The Practice of Multiple Umrah Trips among Middle Class in Yogyakarta. Perpustakaan Pusat UGM: Tesis CRCS UGM, 2014.

Muhadjir, Noeng. Metodologi Keilmuan: Paradigma Kualitatif, Kuantitatif, Dan Mixed. Yogyakarta: Rake Sarasin, 2007.

Nazaruddin, M. Nasrun, et al. “Analisis Strategi Pemasaran Dan Pelayanan Dalam Upaya Peningkatan Daya Saing Biro Perjalanan Haji Dan Umrah Perspektif Ekonomi Syariah (Studi Pada PT. Makkah Multazam Safir Dan Al Madinah)." NIZHAM 8, no. 1 (2020): 96.

Tribakti: Jurnal Pemikiran Keislaman

Volume 32, Nomor 1, Januari 2021 
Nuri, Muhammad. "Pragmatisme Pelaksanaan Haji Di Indonesia.” SALAM: Jurnal Sosial Dan Budaya Syar'i 1, no. 1 (2014).

Oktara, Kiki \& Achyar, Adriyan. "The Effect Of Post-Purchased Perceived-Value Toward The Relationship Quality Of Hajj And Umrah Travel Agencies In Indonesia." THE SOUTH EAST ASIAN JOURNAL OF MANAGEMENT 8, no. 1 (2014): 30 .

Pals, Daniel L.. Seven Theories of Religion: Tujuh Teori Agama Paling Komprehensif. Yogyakarta: IRCISOD, 2012.

Patton, M.Q. Qualitative Evaluation Methods. London: Sage Publication, 1980.

Prasetijo, Ristiyanti \& Ihalauw, Jhon J.O.L. Perilaku Konsumen. Yogyakarta: Andi Yogyakarta, 2004.

Rahmat, Jalaluddin. Psikologi Agama. Jakarta: Raja Grafindo, 2002.

Raj, Razaq \& Bozonelos. "Pilgrimage Experience and Consumption of Travel to the City of Makkah for Hajj Ritual." International Journal of Religious Tourism and Pilgrimage 3, no. 1 (2015).

Riyanto, Yatim. Metodologi Penelitian Pendidikan. Surabaya: Surabaya, 2001.

Schiffman, Leon G \& Kanuk, Leslies Kazar. Perilaku Konsumen. Jakarta: PT. Macanan Jaya Cemerlang, 2011.

Sobur, Alex. Psikologi Umum. Bandung: CV Pustaka Setia, 2003.

Sucipto. "Umrah Sebagai Gaya Hidup, Eksistensi Diri Dan Komoditas Industri: Menyaksikan Perubahan Keagamaan Warga Kota.” Jurnal Kontekstualita 28, no. 1 (2013).

Sukardi. Metode Penelitian Pendidikan: Kompetensi Dan Prakteknya. Jakarta: Bumi Aksara, 2005.

Walyoto, Sri \& Paranginangin, Jasanta. "Analysis On Demand For Umrah Bailout Fund In Indonesia." International Journal of Civil Engineering and Technology (IJCIET) 9, no. 13 (2018): 1247. 